\title{
Giant Cuban Treefrog (Osteopilus septentrionalis) Tadpoles in an Introduced Population on Nevis (Lesser Antilles)
}

\author{
Kevel Lindsay ${ }^{1}$, Kathleen Orchard ${ }^{2}$, and Mark Yokoyama ${ }^{3}$ \\ ${ }^{1}$ Environmental Awareness Group (EAG), St. John’s, Antigua and Barbuda (kcl927@yahoo.com) \\ ${ }^{2}$ P.O. Box 462, Camps, St. Kitts (kateorchard16@gmail.com) \\ ${ }^{3}$ Association Les Fruits de Mer, Grand-Case, St. Martin (snofoam@gmail.com)
}

$\mathrm{L}$ indsay (2017) described the discovery on 13 February 2017 of very large tadpoles (Fig. 1) of an unknown species in a small pool in an old sugar-boiling copper on the grounds of Morning Star Estate in St. John Figtree Parish, Nevis. Because they were much larger than the larvae of the three anuran species (Cane Toad, Rhinella marina; Cuban Treefrog, Osteopilus septentrionalis; and the direct-developing Lesser Antillean Frog, Eleutherodactylus johnstonei) known to occur on Nevis, the tadpoles were transferred to aquaria with the intent of rearing them to metamorphosis. Two survived long enough to develop fore- and hindlimbs (Fig. 2). Although tentatively identified as Lithobates catesbeianus because of their size, a careful examination of photographs at various stages of development revealed them to be hylids and almost certainly Osteopilus septentrionalis, the only hylid known to occur on Nevis.

These individuals were much larger than sizes typically attained by larval $O$. septentrionalis. Approximately $7 \mathrm{~cm}$ in total length when initially encountered, they grew to $>9 \mathrm{~cm}$

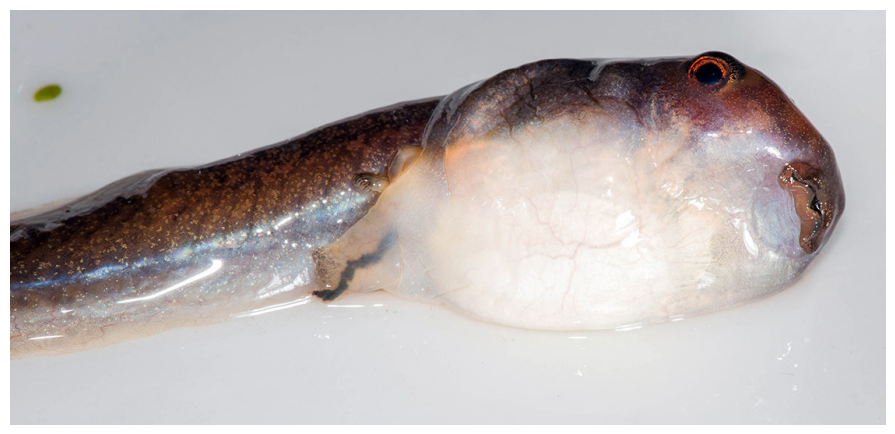

Fig. 1. Very large Cuban Treefrog (Osteopilus septentrionalis) tadpole discovered on 13 February 2017 in a small pool in an old sugar-boiling copper on the grounds of Morning Star Estate in St. John Figtree Parish, Nevis. Photograph by M. Yokoyama.

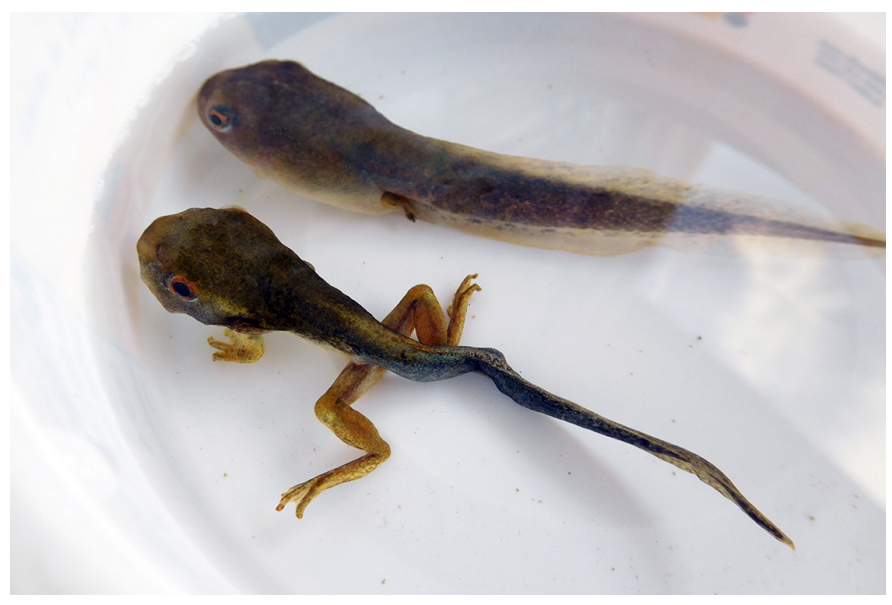

Fig. 2. Cuban Treefrog (Osteopilus septentrionalis) tadpoles on 26 April 2017 with the toes of the lower individual clearly showing the intercalary cartilage typical of frogs in the family Hylidae. Photograph by Kathleen Orchard.

in captivity (Fig. 3). Normal O. septentrionalis tadpoles are known to reach lengths of $32 \mathrm{~mm}$ (Dodd 2013).

The species was first reported on Nevis by Horwith and Lindsay (1999) and was suspected of having arrived with ornamental plants from Florida (USA). These frogs are now abundant and widely distributed; in 2017, tadpoles were observed in natural and artificial freshwater pools across the island to elevations as high as $405 \mathrm{~m}$ asl (J. Daltry, in litt., 20.v.2019).

Gigantism in anuran tadpoles has been reported previously in laboratory populations of Xenopus laevis (e.g., RotNikcevic and Wassersug 2003), in the Pelophylax (formerly Rana) ridibunda species complex (e.g., Milto 2009), Rana temporaria (J. Daltry, in litt., 20.v.2019), Lithobates catesbeianus (Lapin 2018), and Hyla arborea (Boschwitz 1961). This condition apparently is attributable to hormone imbalances or 


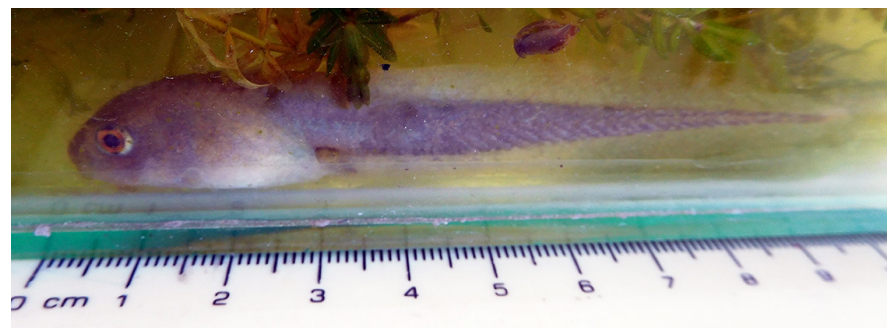

Fig. 3. Cuban Treefrog (Osteopilus septentrionalis) tadpole on 4 May 2017. Photograph by Kathleen Orchard.

athyroidism and, like the two tadpoles on Nevis, these giants died without completing metamorphosis (Rot-Nikcevic and Wassersug 2003).

\section{Acknowledgements}

Wentworth Smithen, St. Kitts and Nevis Department of the Environment, alerted us to the presence of the tadpoles. He and Carolyn Thomas were participants in the ecological survey team. Jennifer Daltry, Fauna \& Flora International, Cambridge, UK, triggered the discussion that led to this note. Ronald Altig, Mississippi State University, was instrumental in resolving the mystery of the giant tadpoles. The discov- ery of the tadpoles occurred during the project "Conserving Biodiversity and Reducing Habitat Degradation in Protected Areas and Their Areas of Influence, St. Kitts and Nevis," under the auspices of the Department of the Environment, Government of The Federation of St. Kitts and Nevis, and the United Nations Development Programme (UNDP).

\section{Literature Cited}

Boschwitz, D. 1961. A giant tadpole of Hyla arborea L. Bulletin of the Research Council of Israel 10B: 173-174.

Dodd, C.K., Jr. 2013. Frogs of the United States and Canada. Volume 2. The Johns Hopkins University Press, Baltimore, Maryland.

Lapin, T. 2018. Researchers catch biggest tadpole on record. New York Post, 14 June 2018. <https://nypost.com/2018/06/14/researchers-catch-gigantic-tadpole-in-arizona/>.

Horwith, B. and K. Lindsay. 1999. A Biodiversity Profile of St. Kitts and Nevis. Island Resources Foundation, St John's, Antigua.

Lindsay, K. (not credited). 2017. The mystery Nevis 'Monster' (Conserving Biodiversity Project). UNDP (United Nations Development Programme) Barbados \& the OECS (Organization of Eastern Caribbean States), Castries, St. Lucia. <http:// www.bb.undp.org/content/barbados/en/home/presscenter/articles/2017/04/10/ the-mystery-nevis-monster-conserving-biodiversity-project-.html>.

Milto, K.D. 2009. A giant tadpole record of Rana esculenta in northwestern Russia. Russian Journal of Herpetology 16: 143-145.

Rot-Nikcevic, I. and R.J. Wassersug. 2003. Tissue sensitivity to thyroid hormone in athyroid Xenopus laevis larvae. Development, Growth \& Differentiation 45: 321-325. 